\title{
Effect of different post-cure polymerization treatment on composite resin hardness
}

\author{
Efeito de diferentes métodos de polimerização complementar sobre a dureza de resinas compostas
}

Ariani Rodrigues DIMER ${ }^{1}$

Guilherme Anziliero AROSSI ${ }^{1}$

Leonardo Haerter dos SANTOS 2

Diego Rafael KAPPAUN ${ }^{3}$

\section{ABSTRACT}

\section{Objective}

To evaluate the influence of different additional polymerization methods on the microhardness of two direct composite resins.

\section{Methods}

Direct Composite resins samples (Fill Magic and Opallis) and a Laboratory Composite Resin (Ceramage) were lightcured according to manufacturer instructions. Then, the direct resins were submitted to additional polymerization. Experimental groups were divided into $(n=5)$ : group 1: Conventional Polymerization; group 2: Extra Light (80s); group 3: Autoclave; group 4: Laboratory Resin Ceramage. Vickers hardness test was carried out after a week of light-free storage in water, and results were subjected to ANOVA / Tukey statistical analysis.

\section{Results}

Resin Lab Ceramage showed higher astatistically significant microhardness within all other resins in this study ( $p \leq 0.05)$; Fill Magic showed no statistically significant difference between the groups tested compared to its control ( $p>0.05)$; Opallis resin submitted to autoclave was the only method that showed a higher statistically significant difference compared to the control group $(p \leq 0.05)$.

\section{Conclusion}

It concludes that hardness of a direct composite resin tested - Opallis - was increased by Autoclave post-cure polymerization, however, not enough to achieve the hardness of a laboratory composite. Furthermore, increasing lightcuring time does not produce a harder surface.

Indexing terms: Hardness. Hot temperature. Polymerization.

\section{RESUMO}

\section{Objetivo}

Avaliar a influência de diferentes métodos de polimerização complementar na microdureza de duas resinas compostas de uso direto.

\section{Métodos}

As amostras foram confeccionadas com as resinas FillMagic, Opallis e Ceramage (Resina Composta Laboratorial); e fotopolimerizadas conforme recomendações do fabricante. Em seguida, as resinas de uso direto foram submetidas à polimerização complementar. Os grupos experimentais foram divididos em ( $n=5)$ : grupo 1: Fotopolimerização convencional; grupo 2: Luz adicional (80s); grupo 3: Autoclave; grupo 4: Resina Laboratorial Ceramage. O ensaio de microdureza Vickers foi realizado após uma semana de armazenagem em água, em invólucros livres de luz, e os resultados foram submetidos à análise estatística ANOVATTukey.

\section{Resultados}

A Ceramage apresentou maior valor de microdureza Vickers, com diferença significativa em relação a todas as outras resinas utilizadas neste estudo ( $p \leq 0,05)$; a FillMagic não apresentou diferença significativa entre seus grupos experimentais e o seu controle $(p>0,05)$; na Opallis, a autoclave foi único método que apresentou diferença significativa quando comparado ao seu grupo controle $(p \leq 0,05)$.

\section{Conclusão}

Conclui-se que a dureza de uma resina composta de uso direto testada - a Opallis - foi aumentada pela polimerização complementar em Autoclave, porém, não foi suficiente para atingir a dureza da resina composta laboratorial. Além disso, o aumento no tempo de fotoativação das resinas de uso direto não produz uma superfície de maior dureza.

Termos de indexação: Dureza. Temperatura alta. Polimerização.

\footnotetext{
${ }^{1}$ Universidade Luterana do Brasil, Curso de Odontologia, Campus Torres. Rua Universitária, 1900, Parque Balonismo, 95560-000, Torres, RS, Brasil. Correspondência para / Correspondece to: AR DIMER. E-mail: <ani_dimer@hotmail.com>.

${ }^{2}$ Universidade Luterana do Brasil, Departamento de Engenharia Mecânica, Campus Canoas. Canoas, RS, Brasil.

${ }^{3}$ Universidade Luterana do Brasil, Curso de Engenharia Química. Canoas, RS, Brasil.
} 


\section{INTRODUCTION}

At the moment of choosing the restorative material to be used, the advantages, disadvantages, and the intrinsic characteristics of this material, such as aesthetics, mechanical properties, surface finishing, polymerization shrinkage and cost / benefit, are evaluated. With the aesthetic demand in restorative procedures, there has been a gradual replacement of metal alloys and silver amalgam restorations with resin systems ${ }^{1}$. The clinical use of composite resin has expanded in restorative dentistry, with indication to direct and indirect restorations, mainly due to their aesthetic quality and good physical properties ${ }^{2-3}$.

Direct resins promote a strengthening of the tooth structure and good clinical performance ${ }^{4}$. Nevertheless, there are some problems related to direct restorative technique such as polymerization shrinkage. Such contraction may result in the formation of cracks in the tooth / restoration interface, causing microleakage and postsurgical sensitivity, harming major dental reconstructions with direct composite resin. In addition, another problem refers to the execution of the direct technique being more complicated because it requires skill for carving the restoration and preparing proper points of approximal contact, especially in large dental damage; and it also requires finishing and polishing procedures ${ }^{5}$.

As a clinical alternative, you can choose to make indirect composite resin restorations for extensively damaged teeth ${ }^{6}$. Research on polymers and ceramic technology aimed at improving mechanical and physical properties of indirect resins led to the incorporation of multifunctional glass particles and methacrylate in their compositions ${ }^{1,6}$. Indirect or laboratory resins present high density of inorganic ceramic particles compared to traditional direct composites, and a change in the resin matrix, with the inclusion of multifunctional monomers with more binding sites, increasing the polymerization chains with additional curing by heat and pressure in oxygen-free environments Most indirect resin systems use heat in the process of additional polymerization, resulting in an increase of its hardness, flexural strength, fracture toughness and wear resistance, in addition to greater color stability?.

During this post-polymerization process, the movement and alignment of monomers take place, forming the polymer chains, from the union of the active sites of these monomers with double carbon bonds ${ }^{7}$. The breaking of these double monomer bonds into single bonds is defined as degree of conversion, and its variations may affect the physical properties of resin systems. The degree of conversion varies according to the composition of the materials, including monomeric systems, initiator and solvent concentration, amount and type of particles ${ }^{8-10}$.

With the polymerization of a composite, the highest polymerization conversion possible is desired, as the material will present better physical, chemical and mechanical properties ${ }^{11}$. Thus, some studies have suggested additional heat polymerization in composite resins in order to increase the degree of conversion and, therefore, improve their properties ${ }^{12-17}$. Such evidence suggests the use of suitable composites for direct procedures, undergoing additional polymerization, in preparing indirect procedures. Laboratory-made indirect resins are often polymerized by specific equipment, raising the cost of this type of work. One way to solve this problem would be using previously lightcured direct resins, and carrying out additional polymerization by heat with the equipment available at the dentist's office, such as autoclave, stove or microwave ${ }^{2}$. Thus, the polymerization shrinkage pressure is eliminated, which shall take place outside the oral cavity, and also improves the polymer conversion degree.

There are some methods for measuring the degree of conversion of the resinous composites and one of the most used is the infrared spectroscopy, which measures the amount of double bonds before and after polymerization, determining the degree of conversion ${ }^{15}$. Another method is the surface hardness test (Vickers or Knoop), where a diamond adapted to a compression machine with an attached microscope promotes an indentation on the test corpus, obtaining a surface hardness value for the material. The greater the toughness presented by the material is, the greater the degree of conversion of the matrix resinous will be bi-13. $^{12}$

Aiming at making the indirect restoration process more accessible, with the use of direct composite resins associated with additional polymerization methods, this study aimed at evaluating the influence of different methods of additional polymerization in the microhardness of two direct composite resins.

\section{METHODS}

The materials used in this experiment were the direct composite resins Opallis (FGM, Joinville, Brazil) and FillMagic (Vigodent S.A. Ind. Com. Bonsucesso, RJ, Brazil..) resins; and laboratory composite resin Ceramage (Shofu Dental Corporation, Kyoto, Japan). Details of the materials are described in Chart 1. 
Chart 1. Description of the resins used in this study.

\begin{tabular}{|c|c|c|}
\hline Composite resin & Characteristics & Composition \\
\hline $\begin{array}{c}\text { Opallis } \\
\text { (\#Batch 30911) } \\
\text { FGM, Joinville, SC, Brasil }\end{array}$ & $\begin{array}{c}\text { Microhybrid, } \\
\text { Direct composite resin }\end{array}$ & $\begin{array}{c}\text { Average particle size of } 0.5 \mu \mathrm{m} \text {, total content of weight load from } 78.5 \% \\
\text { to } 79,8 \% \text { and volume from } 57 \text { to } 58 \% \text { Bis-GMA, Bis-EMA, UDMA and } \\
\text { TEGDMA. The loads are a combination of silanized barium-aluminum silicate } \\
\text { glass and nanoparticles of silicon dioxide, camphorquinone as photoinitiator, } \\
\text { accelerators, stabilizers and pigments. }\end{array}$ \\
\hline $\begin{array}{l}\text { Fill Magic } \\
\text { (\#Batch 1300662) } \\
\text { Vigodent S.A. Ind. Com. } \\
\text { Bonsucesso, RJ, Brasil }\end{array}$ & $\begin{array}{l}\text { Microhybrid, direct } \\
\text { composite resin }\end{array}$ & $\begin{array}{l}\text { Average particle size of } 0.5 \mu \mathrm{m} \text {, with an average percentage of weight load } \\
\text { of } 75 \% \text {, comprised of Bis-GMA, Bis-EMA, UDMA, TEGMA, photoinitiator, } \\
\text { loads and pigments. }\end{array}$ \\
\hline $\begin{array}{l}\text { Ceramage } \\
\text { (\#Batch 041280) } \\
\text { Shofu Dental Corporation, } \\
\text { Kyoto, Japan }\end{array}$ & $\begin{array}{l}\text { Micro-ceramic hybrid, } \\
\text { Laboratory composite resin }\end{array}$ & $\begin{array}{c}73 \% \text { of zirconium silicate-based microfine ceramic load (PFS load, } \\
\text { Progressive Fine Structured Filler). The composition is supported by an } \\
\text { organic polymer matrix }\end{array}$ \\
\hline
\end{tabular}

Note: Abbreviations: Bis-GMA: bisphenol-A glycidylmetaclorate; Bis-EMA: Bisphenol-A-polyethylene glycol diether-dimethacrylate; TEGDMA: triethyleneglycoldimethacrylate; TEGMA: Triethylene glycol methacrylate UDMA: urethane dimethacrylate,

\section{Preparation of samples}

To characterize the variable "resin type", 15 samples of FillMagic resin and 15 samples of Opallis resin, A2 color were made in a split steel matrix with a diameter of $3 \mathrm{~mm}$ at the bottom, $4 \mathrm{~mm}$ at the top and a width of $2 \mathrm{~mm}$. For this purpose, a polyester matrix strip was positioned on a metallic surface and, on the strip, a steel matrix was placed in order to prepare the samples was placed. The composite resin was inserted on the matrix cavity in single increment of $2 \mathrm{~mm}$. A new matrix strip was placed on the resin inserted in the metal matrix and another metal surface was pressed on it for about 5 seconds, to obtain a flat surface - which was important for the hardness reading. Then, the metal plate was removed and the lightcure was performed on the matrix strip for the time recommended by the manufacturer of each resin and using a LED photopolymerizer with a power of $400 \mathrm{~mW} / \mathrm{cm}^{2}$ (Light Emitting Diode - LD Max Gnatus, São Paulo, Brasil).

Five samples of laboratory composite resin Ceramage comprised the Positive Control Group, and were made in a dental prosthesis laboratory by the TPD in charge, following the manufacturer's recommendations.

\section{Experimental groups}

Samples of the direct composite resins were randomized into 3 groups $(n=5)$ :

a) group 1 (G1) - Negative control group: Lightcure at the top of the sample for 20 seconds in Opallis resin and for 40 seconds in FillMagic resin, as recommended by the manufacturer;

b) $\quad$ group 2 (G2) - Additional light. Lightcure on top of the sample for 80 seconds on both resins;

c) group 3 (G3) - Additional Polymerization in an autoclave (Ortosintese, São Paulo, Brasil). The samples of this group, after receiving the lightcure protocol performed in group 1, were immediately packed separately in transparent plastic bags prepared to be used in autoclave, properly cut specifically for the case and sealed with a heat sealer. All samples in this group underwent the same autoclave cycle $\left(134^{\circ} \mathrm{C}, 7\right.$ minutes, $\left.2.5 \mathrm{Kg} / \mathrm{cm}^{3}\right)$;

d) group 4 (G4) was comprised by Positive Control, represented by the laboratory composite resin Ceramage $(n=5)$.

Thus, the experimental groups characterize the variable "polymerization method". The variables formed by the "resin type "and the" polymerization method "can be observed in Chart 2.

After additional polymerization, the samples were polished with a 600-grit water sandpaper (Norton Abrasives, Guarulhos, Brazil) on the top surface for 5 seconds. The specimens were then stored for one week at room temperature in sealed bottles containing black water, so as to prevent access of light to the specimens.

Chart 2. Distribution of the study variables.

\begin{tabular}{cccc}
\hline Polymerization method & G1 & G2 & G3 \\
\hline $\begin{array}{c}\text { Resin type } \\
\text { A - Opallis }\end{array}$ & 20s top light & 80s top light & 20s top light + autoclave \\
B - FillMagic & 40s top light & 80s top light & 40s top light + autoclave \\
C - Ceramage & & & 3 min. of light + 15 min. stove. \\
\hline
\end{tabular}




\section{Method to evaluate the results and for statistical analysis}

After seven days, the specimens were submitted to hardness test on a Vickers type microdurometer (INSIZE, São Paulo, Brazil), which has a diamond indenter with pyramidal base. For this, a load of $100 \mathrm{gf}$ was applied for 10 seconds. Three indentations were carried out, one at the center and two at the ends, on top of each specimen test piece. The specimens were analyzed by another examiner to obtain blinding in data collection. The average of each group was obtained from the three values of hardness obtained on each surface. These average values were considered as dependent variable for statistical analysis. The independent variables "resin type" and "polymerization method" were compared with one another using the one-way ANOVA variance analysis with identification of individual significance held by Tukey test, considering statistically significant difference when $\mathrm{p} \leq 0,05^{18-19}$.

\section{RESULTS}

The results may be observed in Table 1, which shows the average values and standard deviation of the Vickers hardness number (VHN) of the variables "resin type" and "polymerization method".

Table 1. Average and standard deviation of the Vickers hardness of two direct composite resins and two indirect composite resin.

\begin{tabular}{lcc}
\hline Groups & Resins & Microhardness (VHN)* \\
\hline Control & Opallis & $17.23(2.23)^{\mathrm{E}}$ \\
& Fill Magic & $24.55(4.70)^{\mathrm{B}}$ \\
Additional Light & Opallis & $19.49(1.65)^{\mathrm{DE}}$ \\
& Fill Magic & $23.16(0.94)^{\mathrm{BCD}}$ \\
Autoclave & Opallis & $21.09(0.72)^{\mathrm{BCD}}$ \\
& Fill Magic & $24.79(3,35)^{\mathrm{B}}$ \\
Laboratory & Ceramage & $30.67(5.65)^{\mathrm{A}}$ \\
\hline
\end{tabular}

Note: Different capital letters in the same column indicate statistically significant differences $(p \leq 0.05)$. * VHN = Vickers Hardness Number, unit of measurement of hardness used in the experiment.

The Ceramage resin showed the highest value of Vickers microhardness (30.67), with statistically significant difference from all other resins used in this study, regardless the polymerization method.

Regarding the polymerization method in the control group (G1), the FillMagic showed higher microhardness (24.55), and this group presented statistically significant difference $(p<0.001)$ when compared to Opallis (17.23). In the Additional Light (G2) and Autoclave (G3) groups, FillMagic $(G 2=23.16$ and $G 3=24.79)$ and Opallis
( $G 2=19.49$ and $G 3=21.09)$ presented no significant statistically difference between each other ( $p=0.071$ in $G 2$ and $p=0.067$ in $G 3$ ).

In contrast, in Opallis, Autoclave $(G 3=21.09)$ was the only method of additional polymerization that showed a significant statistically difference $(p=0.044)$ comparing to the control group $(\mathrm{G} 1=17.23)$, as the Additional Light group ( $G 2=19.49$ ) showed no difference compared to the control $(p=0.663)$.

In FillMagic there was no significant statistically difference among the groups tested related to their control.

\section{DISCUSSION}

The laboratory composite resin Ceramage showed the best results of Vickers microhardness related to the direct use of resins, which, even with additional polymerization, did not obtain statistically significant improvement. In literature, we have found data that go along with our results $20-21$, also demonstrating higher hardness values that comes from other laboratory resin over several different direct resins used in this experiment as well as over the FillMagic resin.

From the results of this study, it was possible to notice that direct composite resins did not achieve significant improvement in top hardness when subjected to additional polymerization, except for the Opallis resin, postpolymerized in Autoclave. Although some studies showed an increase in the microhardness of composite resins promoted by various complementary polymerization methods ${ }^{2,16-17,22}$, our results did not identify this difference, what can be explained by the composition of resins, which influences the degree of conversion of heat-induced polymer chains. In a hardness evaluation study, the Opallis resin showed a nonsignificant increase in hardness when subjected to additional polymerization in autoclave ${ }^{22}$. In our results, this increase in hardness was statistically significant compared to the control group, which received only the traditional lightcuring.

In another study, three microhybrid composite resins were selected, among them the Opallis, which were submitted to polymerization with a halogen device and a LED. The lowest hardness averages were found in the Opallis resin, which corroborates the results of this experiment. The author suggests that the co-initiator is not activated with the length of light emitted by the lightcuring device, since it is not specified by the manufacturer in the technical resin profile ${ }^{8,21}$.

The completion of lightcuring with longer exposure to light increased the hardness of Opallis, although without statistical significance. However, comparing it to the 
FillMagic resin, which, lightcured in the traditional manner, had better significant results, there was no difference between resins in the additional light group, indicating an improvement of its properties. Clinically, these results suggest that lightcuring can be supplemented even in restorations made by direct technique, in order to obtain better performance of the restoration material.

There is evidence in the literature that the Fill Magic resin showed no significant increase in Knoop microhardness when subjected to heat treatment in a blast furnace $\left(170^{\circ} \mathrm{C} / 10\right.$ minutes). In the same study it was noted that composites with less inorganic load presented significant improvements in hardness after heat application ${ }^{23}$. Another author has also shown in his results that there was no increase in hardness for the FillMagic resin when subjected to additional polymerization in autoclave $^{12}$. In our results, the use of the heat was not capable of significantly increase the hardness of the surface, which goes along with the literature and suggests that this form of post-cure is not effective for this composite.

Restorative materials have evolved, and composite resins started to incorporate to its organic matrix other monomers such as UDMA and Bis-EMA. Resins with this composition have higher molecular weight than resins based on Bis-GMA and TEGDMA. As a consequence, they have fewer double bonds per weight unit, which enables the material to have a higher degree of conversion when exposed to light, as well as less polymerization shrinkage and water absorption ${ }^{24}$. This statement agrees with the findings of Loguercio et al. ${ }^{25}$, who have reported that the addition of UDMA over TEGDMA promoted an improvement of mechanical properties related to bis-GMA composite base, in addition to having a higher degree of conversion. This may explain why the additional polymerization used in this study showed no increase in hardness, except for Opallis in Autoclave, as both direct composite resins used presented UDMA and Bis-EMA in its composition, characterizing them as good materials for direct use.

The experiment may have potential limitations that influence the results, which should be considered,

AR DIMER, GA AROSSI, LH SANTOS DR KAPPAUN who participated in all stages of the preparation of this article.

\section{REFERENCES}

especially for being an in vitro study. The samples must have flat surface to implement the Vickers hardness test; the sample number may be another bias factor in obtaining the data, however, this experiment used an appropriate sampling as shown in the literature ${ }^{19,26}$.

Our work is clinically relevant, as by testing surface microhardness of composite resins, we are providing information on the mechanical properties of these materials to the dental surgeon ${ }^{27-28}$. The hardness is directly related to wear resistance, as evidenced in the literature, establishing a correlation where the higher the hardness, the lower the surface wear of the composite resin ${ }^{18,29-30}$. Wear resistance is one of the main properties of a composite and the capability of the material to be suitable for use in areas of masticatory effort depends on it. Thus, it is possible to obtain clinically relevant information regarding the performance of different restorative materials and polymerization methods by performing an in vitro test of simple execution.

\section{CONCLUSION}

We conclude with this experiment, that the hardness of a direct composed resin used - the Opallis - was increased by additional polymerization in autoclave, however, it was not enough to achieve the hardness of laboratory composite resin, which showed the highest values among the materials used. Furthermore, it can be concluded that the increase in lightcuring time for the direct composite resins tested does not produce a harder surface.

\section{Acknowledgments}

I greatly appreciate the cooperation of Zardo Daniel, for his attention and understanding in carrying out this study, as well as Professor William and Leonardo and graduate Diego.

\section{Collaborators}

1. Garcia LFR, Consani S, Churata RLM, Souza FCPP. Resinas indiretas: evolução histórica. Clin Pesq Odontol. 2006;2(5/6):407-11.

2. Araújo AR, Medeiros ML, Rodrigues CDT, Gonçalves AR. Avaliação de três métodos de ativação complementar sobre a dureza superficial de resinas compostas diretas. Robrac. 2009;18(47):28-33. 
3. Poggio C, Lombardini M, Gaviati S, Chiesa M. Evaluation of Vickers hardness and depth of cure of six composite resins photo-activated with different polymerization modes. J Conserv Dent. 2012;15(3):237-41. doi: 10.4103/09720707.97946

4. Busato ALS, Baldissera RA, Bueno M. Avaliação clínica de 5 anos de resinas compostas em dentes posteriores. RGO, Rev Gaúch Odontol. 1996;44(3):165-71.

5. Dickerson WG, Hastings JH. Indirect composite restorations. Curropin Cosmetic Dent. 1995:51-6.

6. Reis JMSN, Jorge EG, Silva RHBT, Segalla JCM, Faria IR, Pinelli LAP. Resina composta indireta como alternativa funcional e estética em reabilitações protéticas. Full Dent Sci. 2012;3(10):193-7.

7. Santos MJMC, Silva Souza Jr MH, Mondelli RFL. Novos conceitos relacionados à fotopolimerização das resinas compostas. JBD J Bras Dent Estét. 2002:1(1):14-21.

8. Gonçalves LS, Spazzin AO, Consani S, Mesquita MF, Galafassi $D$, Júnior BC. Influência do tempo de fotoativação na resistência à flexão de compósitos restauradores. RFO. 2008;13(2):56-60.

9. Da Silva EM, Poskus LT, Guimaraes JG, Barcellos AD, Fellows CE. Influence of light polymerization modes on degree of conversion and crosslink density of dental composites. J Mater Sci Mater Med. 2008;19(3):1027-32. doi: 10.1007/s10856-007-3220-5

10. Neves $A D$, Discacciati JAC, Oréfice RL, Jansen WC. Correlação entre grau de conversão, microdureza e conteúdo inorgânico em compósitos. Pesqui Odontol Bras. 2002;16(4):349-54. doi: 10.1590/S1517-74912002000400012

11. Barszczewska-Rybarek IM. Characterization of urethanedimethacrylate derivatives as alternative monomers for the restorative composite matrix. Dent Mater. 2014;30(12):133644. doi: 10.1016/j.dental.2014.09.008

12. Ribeiro BCl, Boaventura JMC, Gaião U, Saad JRC, Candido MSM Efeito de fontes de luz na microdureza de resinas compostas. RGO, Rev Gaúch Odontol. 2011;59(2):229-36.

13. Wendt Jr SL. The effect of heat used as secondary cure upon the physical properties of three composite resin. II. Wear, hardness and color stability. Quintessence Int. 1987;18(5):351-6.

14. Santana IL, Pacheco DAP, Carvalho FLGL, Raposo CC, Cabral Júnior AA. Caracterização térmica de compósitos dentais e sua importância nas propriedades mecânicas. Rev Pesq Saúde. 2011;12(3):28-31.

15. Bagis $Y$, Rueggeberg FA. Effect of post-cure temperature and heat duration on monomer conversion of photoactived dental resin composite. Dent Mater. 1997;13:228-32. doi: 10.1016/ S0109-5641(97)80033-4

16. Mota EG, Oshima HMS, Burnett Jr LH, Spohr AM, Carvalho LMNP. Influencia de la polimerización adicional em las propiedades de una resina Ormocer. Av Odontoestomatol. 2006;22(5):271-7.

17. Arossi GA, Ogliari F, Samuel SMW, Busato ALS. Polimerização complementar em autoclave, microondas e estufa de um compósito restaurador direto. Rev Odonto Ciência. 2007;22(56):177-80.
18. Topcu FT, Erdemir U, Sahinkesen G, Yildiz E, Uslan I, Acikel C. Evaluation of microhardness, surface roughness, and wear behavior of different types of resin composites polymerized with two different light sources. J Biomed Mater Res B Appl Biomater. 2010;92(2):470-8. doi: 10.1002/jbm.b.31540

19. Hammouda IM. Effect of light-curing method on wear and hardness of composite resin. J Mech Behav Biomed Mater. 2010;3(2):216-22. doi: 10.1016/j.jmbbm.2009.06.002

20. Knobloch L, Kerby RE, Clelland N, Lee J. Hardness and degree of conversion of posterior packable composites. Oper Dent. 2004;29(6):642-9.

21. Almeida AML. Diferentes métodos de otimização da polimerização de resinas compostas de uso direto [tese]. São Paulo: Universidade de São Paulo; 2005.

22. Poskus LT, Latempa AMA, Chagas MA, Silva EM, Leal MPS, Guimarães JGA. Influence of post-cure treatments on hardness and marginal adaptation of composite resin inlay restorations: An in vitro study. J Appl Oral Sci. 2009;17(6):617-22. doi: 10.1590/S1678-77572009000600015

23. Santana IL, Mendes Júnior JG, Corrêa CS, Gonçalves LM, Souza EM, Sousa RC. Effects of heat treatment on the microhardness of direct composites at different depths of restoration. Rev Odonto Cienc. 2012;27(1):36-40. doi: 10.1590/S198065232012000100007

24. Bağis $Y H$, Rueggeberg FA. Mass loss in urethane/TEGDMA- and Bis-GMA/TEGDMA-based resin composites during post-cure heating. Dent Mater. 1997;13(6):377-80. doi: 10.1016/S01095641(97)80110-8

25. Loguercio $A D$, Reis $A$, Poskus $L T$, Rodrigues Filho LE, Busato ALS, Bauer JRO. Avaliação de propriedades mecânicas de diferentes resinas compostas. RBO. 2001;58(6):35-8.

26. Cao L, Zhao X, Gong X, Zhao S. An in vitro investigation of wear resistance and hardness of composite resins. Int J Clin Exp Med. 2013;6(6):423-30

27. Reis A, Poskus LT, Bauer JRO, Loguercio AD, Ballester RY. Avaliação da dureza Vickers e da resistência flexural de resinas compostas compactáveis. Pesqui Odontol Bras. 2000;14(Supl):122.

28. Tantbirojn D, Versluis A, Cheng YS, Douglas WH. Fracture toughness and microhardness of a composite: do they correlate? J Dent. 2003:31(2):89-95. doi: 10.1016/S0300-5712(03)00008-3

29. Say EC, Civelek A, Nobecourt A, Ersoy M, Guleryuz C. Wear and microhardness of different resin composite materials. Oper Dent. 2003;28(5):628-34

30. Mayworm CD, Camargo SS Jr, Bastian FL. Influence of artificial saliva on abrasive wear and microhardness of dental composites filled with nanoparticles. J Dent. 2008;36(9):703-10. doi: 10.1016/j.jdent.2008.05.001 